\title{
A Study of the Microbial Community at the Interface between Granite Bedrock and Soil Using a Culture-Independent and Culture-Dependent Approach
}

\author{
Karen Olsson-Francis ${ }^{1}$, Victoria K. Pearson², Paul F. Schofield ${ }^{3}$, Anna Oliver ${ }^{4}$, \\ Stephen Summers ${ }^{5}$ \\ ${ }^{1}$ Department of Environment, Earth and Ecosystems, The Open University, Walton Hall, Milton Keynes, UK \\ ${ }^{2}$ Department of Physical Sciences, The Open University, Walton Hall, Milton Keynes, UK \\ ${ }^{3}$ Department of Earth Sciences, Natural History Museum, Cromwell Road, London, UK \\ ${ }^{4}$ NERC Centre for Ecology and Hydrology, Benson Lane, Crowmarsh Gifford, Wallingford, UK \\ ${ }^{5}$ Department of Engineering and Innovation, The Open University, Walton Hall, Milton Keynes, UK \\ Email: ${ }^{*}$ k.olsson-francis@open.ac.uk
}

Received 5 January 2016; accepted 28 March 2016; published 31 March 2016

Copyright (C) 2016 by authors and Scientific Research Publishing Inc.

This work is licensed under the Creative Commons Attribution International License (CC BY).

http://creativecommons.org/licenses/by/4.0/

c) (7) Open Access

\section{Abstract}

The dissolution of minerals plays an important role in the formation of soils and sediments. In nutrient limiting soils, minerals constitute a major reservoir of bio-essential cations. of particular interest is granite as it is the major rock type of the continental land mass. Although certain bacteria have been shown to enhance weathering of granite-forming minerals, little is known about the dissolution of granite, at the whole rock scale, and the microbial community involved. In this study, both culture-independent and culture-dependent approaches were used to study the bacterial community at the interface between granite bedrock and nutrient limiting soil in Dartmoor National Park, United Kingdom. High throughput sequencing demonstrated that over $70 \%$ of the bacterial population consisted of the bacterial classes Bacilli, Beta-proteobacteria and Gamma-proteobacteria. Bacteria belonging to the genera Serratia, Pseudomonas, Bacillus, Paenibacillus, Chromobacterium and Burkholderia were isolated from the sample site. All of the isolates were able to grow in a minimal growth medium, which contained glucose and ammonium chloride, with granite as the sole source of bio-essential elements. Sixty six percent of the isolates significantly enhanced basalt dissolution $(p<0.05)$. Dissolution of $\mathrm{Si}, \mathrm{K}, \mathrm{Ca}$ and $\mathrm{Mg}$ correlated with production of oxalic acid and acidification. The results of this study suggest that microorganisms in nutrient limiting soils can enhance the rate of granite dissolution, which is an important part of the biogeo-

${ }^{*}$ Corresponding author.

How to cite this paper: Olsson-Francis, K., Pearson, V.K., Schofield, P.F., Oliver, A. and Summers, S. (2016) A Study of the Microbial Community at the Interface between Granite Bedrock and Soil Using a Culture-Independent and CultureDependent Approach. Advances in Microbiology, 6, 233-245. http://dx.doi.org/10.4236/aim.2016.63023 


\section{chemical cycle.}

\section{Keywords}

\section{Mineral Weathering, Soil Community}

\section{Introduction}

The silicates account for over $90 \%$ of the Earth's crust. The dissolution of silicate minerals results in the formation of soil and sediment, and is an important process in long-term carbon cycling. In nutrient limiting soils, such as acidic soils, silicate minerals also constitute a major reservoir of bio-essential cations, for example, calcium, potassium and magnesium [1]. Microorganisms, such as bacteria and fungi are known to enhance the dissolution rates of silicates (for reviews on the role of fungi and bacteria see [2] and [3], respectively). Bacteria are able to accelerate the rate of elemental release from minerals either directly through the acquisition of limiting nutrients, or indirectly through the production of metabolic by-products that lower the $\mathrm{pH}$ or change the saturation state of the mineral [3]-[12].

Silicate minerals are the principle component of igneous rocks, such as granite, which is the most common rock type of the continental land mass. Microbe-granite interactions may therefore, play an important role in biogeochemical cycling of bio-essential elements. However, there is relatively little known about microbe-granite interactions and the role of microorganisms in granite dissolution. Laboratory-based experiments, with granite-forming minerals, have suggested that microorganisms produce organic acids, siderophores and extracellular polysaccharides that enhance granite dissolution [13] [14]. Yet these studies have predominately focused on single minerals rather than the whole rock scale, where the rate of dissolution and reaction pathways would be different [13]-[17]. Previous experiments have also mainly focused on commercial bacteria rather than bacteria isolated from a granitic environment.

In nutrient limiting soils, a small number of studies have investigated the role of microorganisms in graniteforming minerals using in-situ mesocosm experiments. The presence of minerals has been shown to influence the diversity of the microbial communities [18]-[23]. Long-term experiments have demonstrated a correlation between mineral dissolution and community abundance, in nutrient limiting acidic soils [3] [24]. Yet, it is unclear if the correlation is due to increased bioavailability of inorganic nutrients due to weathering in the surrounding soil or to the active role of microorganisms in weathering [3] [24]. To address the role of bacteria, a parallel culture-independent and culture-dependent approach is required.

In this paper, we investigated the potential role that bacteria perform in granite weathering in nutrient limiting soils. The site for this study was an area within Dartmoor National Park, United Kingdom, which was selected due to the prevalence of granite outcrops (tors), many of which are overlain by shallow soil layers. Insight into the microbial community was obtained using a high throughput sequencing approach. In parallel, the weathering ability of microorganisms was determined by isolating members of the community and carrying out dissolution experiments in batch culture. This investigation is important for understanding the role of microorganisms in bio-geochemical cycling in nutrient limiting soil environments.

\section{Material and Methods}

\subsection{Sample Collection}

The sample sites for this study were within Dartmoor National Park, United Kingdom. Soil samples were collectedin triplicate from four locations within the national park (Site $1,53^{\circ} 36.218 \mathrm{~N}, 3^{\circ} 1.781 \mathrm{~W}$; Site $2,53^{\circ} 3.538 \mathrm{~N}$, $3^{\circ} 1.7152 \mathrm{~W}$; Site $3,53^{\circ} 3.544 \mathrm{~N}, 3^{\circ} 1.7066 \mathrm{~W}$ ), each at the base of a granite outcrop at the rock/soil interface. The overlying soil was easily accessible, shallow (approximately $10 \mathrm{~cm}$ in depth) and was characterised as acidic (Princetown series). The local vegetation at all sites was dominated by Nardus and Moliniagrasses. Samples were collected aseptically in March 2013 using corers and stored as previously described [25]. X-ray diffraction (XRD) and X-ray fluorescence (XRF) analysis confirmed the composition of the bedrock was granite. Anorthoclase, quartz, biotite and kaolinite were identified as the major phases from XRD analysis and the major ele- 
ments were identified with XRF, as shown in Table 1.

\subsection{Community Analysis}

DNA was extracted from each of the soil samples using the bead-beating phenol extraction protocol previously described [26]. The DNA was PCR amplified using a set of primers specific to the V3-V6 hypervariable region of the bacterial 16S rRNA gene [27], which was carried out according to Sogin et al. [28]. Sequencing was carried out using an Ion Torrent Personal Genome Machine (Life Technologies, Paisley UK) with a 316 chip.

\subsection{Bioinformatic Analysis}

The MOTHUR's Costello pipeline was used to processes and analysis the raw sequence data [29]. Reads were removed from further analysis if one of the following criteria were met: 1) the read length was shorter than 150 bp, (2) number of ambiguous bases was greater than zero. The sequences were processed as previously described [25]. Rarefaction curves were generated using MG-RAST [30] and all sequences obtained in this study were submitted to MG-RAST [30], under identification numbers 4548120.3, 4548121.3, 4548122.3 and 4548123.3.

\subsection{Isolation of Bacteria}

Aerobic heterotrophs were isolated from the sample site using agar plates. One gram of soil was scattered onto an agar plate, which contained $0.5 \mathrm{~g}$ of powdered granite (fraction size $<100 \mu \mathrm{m}$ ), $65 \mathrm{of} \mathrm{NH}_{4} \mathrm{Cl} \mathrm{mg} \cdot \mathrm{L}^{-1}$ and $15 \mathrm{~g}$ $\mathrm{L}^{-1}$ of Bacto Agar. The plates were incubated at room temperature, in the dark, for four weeks. Pure cultures were obtained by streaking individual colonies onto fresh plates. Routine growth was maintained in a minimal growth medium that contained the following $\left(\mathrm{mg} \cdot \mathrm{L}^{-1}\right)$ : 10 of $\mathrm{FeCl}_{3}, 150$ of $\mathrm{MgSO}_{4} \cdot 6 \mathrm{H}_{2} \mathrm{O}, 20$ of $\mathrm{CaCl}_{2} ; 20$ of $\mathrm{KCl}, 65$ of $\mathrm{NH}_{4} \mathrm{Cl}, 100$ of $\mathrm{NaNO}_{3}, 70$ of $\mathrm{K}_{2} \mathrm{HPO}_{4}, 60$ of $\mathrm{KH}_{2} \mathrm{PO}_{4}, 20$ of glucose and the $\mathrm{pH}$ was adjusted to $\mathrm{pH}$ 6.5 with $100 \mathrm{mMHCl}$.

The bacteria were identified based on near-full length 16S rRNA gene sequences. Total nucleic acids were extracted from the isolates using the Phe: Chl: Iaa bead beating protocol described by [26]. The 16S rRNA gene was amplified using two sets of primers: 27f-Com2 and Com1-1541r, as previously described [25]. BioEdit software (v.7.1.3.0) was used to align the sequences and the resulting contigs were approximately $1500 \mathrm{bp}$ in length. The nearest sequences were identified in the GenBank database using the BLASTN program [31]. All contiguous sequences were deposited into Genbank, as shown in Table 2.

\section{Table 1. Major oxide composition (weight (\%)) of the granite, Dartmoor national park, United Kingdom.}

\begin{tabular}{|c|c|c|c|c|}
\hline \multirow[t]{2}{*}{ Oxides } & \multicolumn{4}{|c|}{ Weight (\%) } \\
\hline & Site 1 & Site 2 & Site 3 & Site 4 \\
\hline $\mathrm{SiO}_{2}$ & 75.18 & 74.94 & 75.01 & 75.95 \\
\hline $\mathrm{TiO}_{2}$ & 0.15 & 0.06 & 0.08 & 0.12 \\
\hline $\mathbf{A l}_{2} \mathbf{O}_{3}$ & 12.66 & 13.62 & 11.65 & 12.52 \\
\hline $\mathrm{Fe}_{2} \mathrm{O}_{3}$ & 1.91 & 0.95 & 1.95 & 1.02 \\
\hline MnO & 0.07 & 0.05 & 0.06 & 0.02 \\
\hline MgO & 0.22 & 0.07 & 0.14 & 0.15 \\
\hline $\mathrm{CaO}$ & 0.42 & 0.25 & 0.35 & 0.39 \\
\hline $\mathrm{Na}_{2} \mathrm{O}$ & 3.05 & 3.04 & 3.11 & 3.15 \\
\hline $\mathbf{K}_{2} \mathbf{O}$ & 4.73 & 5.23 & 5.54 & 4.87 \\
\hline $\mathbf{P}_{2} \mathbf{O}_{5}$ & 0.19 & 0.201 & 0.19 & 0.22 \\
\hline LOI & 0.68 & 1.18 & 1.01 & 0.99 \\
\hline Total & 99.28 & 99.58 & 99.03 & 99.38 \\
\hline
\end{tabular}

LOI is Loss on ignition. 
Table 2. Identification of the bacteria isolated from the interface between the granitic bedrock and nutrient limiting soil.

\begin{tabular}{|c|c|c|c|c|c|}
\hline Isolate & Genebankno $^{\circ}$ & $\begin{array}{c}\text { Closest GenBank } \\
\text { relative }\end{array}$ & $\begin{array}{c}\text { Sequence } \\
\text { identify (\%) }\end{array}$ & Class & $\begin{array}{l}\text { Siderophore ( } \mu \mathrm{mol} \cdot \mathrm{L}^{-1} \\
\text { EDTA equivalent) }\end{array}$ \\
\hline G_01 & KU245735 & Serratiasp. & $100 \%$ & Gamma-proteobacteria & $0.00 \pm 0.00$ \\
\hline G_05 & KU245737 & Pseudomonas sp. & $100 \%$ & Gamma-proteobacteria & $2.05 \pm 0.20^{* *}$ \\
\hline G_02 & KU245738 & Pseudomonas sp. & $99 \%$ & Gamma-proteobacteria & $0.92 \pm 0.15^{* *}$ \\
\hline G_10 & KU245734 & Paenibacillussp. & $97 \%$ & Bacilli & $1.15 \pm 0.22^{* *}$ \\
\hline G_12 & KU245742 & Bacillus sp. & $100 \%$ & Bacilli & $0.64 \pm 0.23^{* *}$ \\
\hline G_14 & KU245736 & Bacillus sp. & $99 \%$ & Bacilli & $0.85 \pm 0.05^{* *}$ \\
\hline G_20 & KU245739 & Burkholderia & $99 \%$ & Beta-proteobacteria & $1.35 \pm 0.22^{* *}$ \\
\hline G_22 & KU245740 & Burkholderia & $99 \%$ & Beta-proteobacteria & $0.78 \pm 0.15^{* *}$ \\
\hline G_23 & KU245741 & Chromobacterium & $99 \%$ & Beta-proteobacteria & $1.94 \pm 0.09^{* *}$ \\
\hline
\end{tabular}

\subsection{Siderophore Production}

To determine the ability of the isolates to produce siderophores the chromeazurol S liquid assay (CAS) was used [32]. The detection of siderophores was quantified and defined according to Payne [33]. The isolates were grown in the minimal medium, without iron (iron-limited) and siderophore production was measured in stationary stage cells. As a control we used Cupriavidus metallidurans CH34, which has previously been shown to produce siderophores under iron limiting conditions [34].

\subsection{Granite Dissolution Experiment}

The dissolution experiments were carried out in batch culture with granite as the sole source of bio-essential elements. The granite was prepared as previously described [34]. The specific surface area of the ground rock was measured using multi-point BET (Brunauer, Emmett and Teller, at Imperial College London) with $\mathrm{N}_{2}$ and yielded a surface area of $1.26 \mathrm{~m}^{2} \cdot \mathrm{g}^{-1}$. The growth medium for the dissolution experiment contained the following $\left(\mathrm{g} \cdot \mathrm{L}^{-1}\right)$ : 0.2 of glucose, 0.06 of $\mathrm{NH}_{4} \mathrm{Cl}$ and 20 of granite. Two grams of granite, which had been prepared by sonication as previously described [34], was placed in an acid-washed $125 \mathrm{~mL}$ glass Erlenmeyer culture flask and autoclaved at $121^{\circ} \mathrm{C}$ for 15 mins. One hundred $\mathrm{mL}$ of liquid medium was added to the flask and the $\mathrm{pH}$ was adjusted to $\mathrm{pH} 7.0$ with $10 \mathrm{mM} \mathrm{NaOH}$. Prior to inoculation, the isolates were grown in the modified minimal medium for 5 days. The cells were harvested by centrifugation at $4,000 \times \mathrm{g}$, for $5 \mathrm{~min}$, and the pellet was

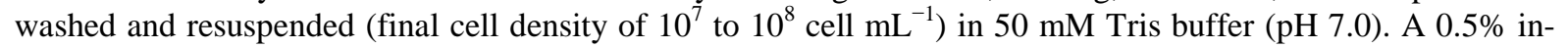
oculum was used to inoculate the flasks. Abiotic controls were prepared in an identical manner to the biological flasks and each treatment was prepared in triplicate.

\subsection{Measuring Microbial Growth}

To monitor microbial growth and $\mathrm{pH}, 1 \mathrm{~mL}$ aliquots were aseptically removed after 1, 4, 7, 14, 21, 28 days. Cells were stained with the nucleic acid-binding dye SYBR Green I DNA $(0.1 \%$ w/v stock; Life Technologies, Paisley, UK). One $\mathrm{mL}$ of culture was filtered through a $0.2 \mu \mathrm{m}$ black polycarbonate filter and then washed with $100 \mu \mathrm{l}$ of $\mathrm{ddH}_{2} \mathrm{O}$. Cells were enumerated using a Leica DMRP microscope equipped with epifluorescence, as previously described [35]. The growth rate constant $(k)$ for the log phase of growth was determined, as previously described [36]. The pH was measured using an Orion 3-Star Thermo Scientific bench top meter.

\subsection{Chemical Analyses}

ICP-MS (Agilent 7500s ICP-MS with New Wave 213 laser system) was used to measure the total concentration of dissolved elements. The initial rate of elemental dissolution was calculated as previously described [16]. Glucose concentration was measured using the Amplex red glucose kit (Invitrogen, Paisley, UK). The absorbance was measured at $595 \mathrm{~nm}$ and compared with a calibration curve of known glucose concentrations. Oxalate was measured using an oxalate oxidase assay (Trinity Biotech), at $590 \mathrm{~nm}$, as per manufacturer's instructions. 


\subsection{Statistical Analysis}

Statistical analysis was carried out using Open source R stat version 3.0.3 (R Development Core Team, 2010), using the Vegan Package [37]). Overall differences in taxa, at the four sample sites, were compared using an ANOSIM test of difference [38]. Confirmation of the significance of any differences was identified using independent $t$-test. The ANOVA test in Microsoft Excel was used to determine a relationship between chemical dissolution and specific growth rates.

\section{Results}

\subsection{Composition of the Bacterial Community}

Ion torrent was used to identify the major bacterial classes at the interface between the outcrop and the soil. Each of the sample sites were represented by 74934 (Site 1), 76631 (Site 2), 72941 (Site 3) and 51703 (Site 4) bacterial sequences. Based on the rarefaction, the qualitative OTU ( $97 \%$ sequence similarity) richness, for each sample site, was high and did not appear to reach asymptote (Figure 1). Taxonomical assignment of the sequences demonstrated that over $85 \%$ of the microbial community was dominated by three bacterial classes (Figure 2). The most abundant class was the Beta-proteobacteria (Site 1, 39.98\%; Site 2, 38.90\%; Site 3, 42.38\%; Site 4, 39.44\%), which represented an overall relative abundance of $40.17 \% \pm 1.33$. This was followed by Bacilli $(23.73 \% \pm 0.166 \%)$ and Gamma-proteobacteria $(10.78 \% \pm 0.56 \%)$. The dataset consisted of $19.10 \% \pm$ $1.04 \%$ of unclassified sequences, overall.

\subsection{Microbial Isolates}

From the powdered granite plates eight isolates were obtained, which belonged to the bacterial classes, Bacilli, Gamma-proteobacteria and Beta-proteobacteria, as shown in Table 2. The Gamma-proteobacteria isolates were related to the genus Pseudomonas (G_02, and G_05) and Serratia (G_01). The majority of the Bacilli isolates showed similar identities to cultivated strains of the genus Bacillus ranging from 99\% to 100\% (G_02 and G_14). The Beta-proteobacteria showed similar identities to Burkholderia (G_20 and G_22) and Chromobacterium (G_23). Each of the isolates listed in Table 2 were screened for siderophore production using the Chrome Azurol S assay. In the minimal medium, without iron, seven of the isolates produced siderophores $(p<0.05)$, as shown in Table 2. However, in the glucose- $\mathrm{NH}_{4}$ medium with granite we were unable to detect any siderophore production (data not shown).

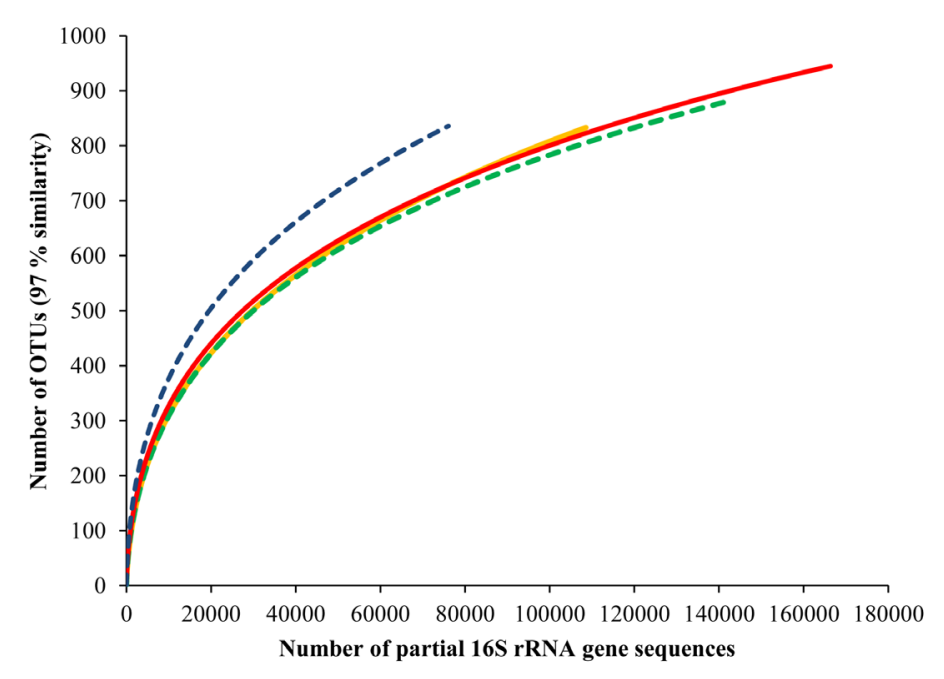

Figure 1. Rarefaction curves of the partial bacterial 16S rRNA gene sequences obtained from the interface between granite bedrock and nutrient limiting soil, using Ion Torrent. The curves show the relationship between the increased number of bacterial OTUs ( $97 \%$ sequence similarity) and the number of randomly samples sequences from each sample site (Site 1 (---); Site 2 (-); Site 3 ( ) and Site 4 (----). 


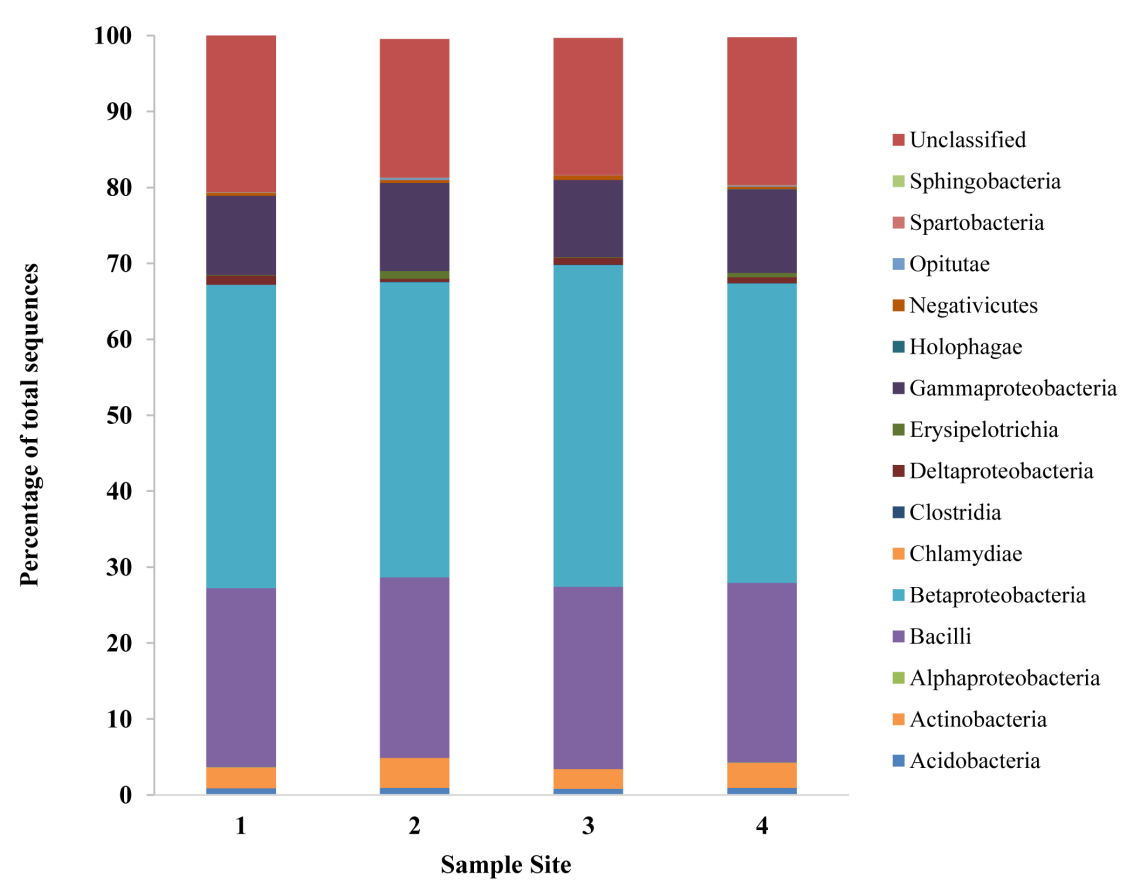

Figure 2. The relative abundance of the 16 most common bacterial classes identified at the interface between the granitic bedrock and the nutrient limiting soil, at the four sample sites in Dartmoor, National Park, UK. Each sample was analysed in triplicate and the sequences for each sample site were pooled together.

\subsection{Granite Weathering Experiment}

The isolates were able to grow in glucose- $\mathrm{NH}_{4}$ medium with granite, but not in the absence of granite. As demonstrated in Figure 3, growth varied between each of the isolates. For example, at 7 days G_05 was in stationary phase (Figure 3(b)); whilst G_10 was in early exponential phase (Figure 3(h)). For each of the isolates, the pH of the growth media decreased during growth, dropping during exponential growth to between 3.0 and 3.5, and then increasing to a steady-state equilibrium of between $\mathrm{pH} 4.0$ and 6.0 (Figure 3). The bacteria consumed the glucose as a carbon source, which was demonstrated by a decrease in glucose concentration during growth (Figure 4(a)). As the glucose was consumed oxalate was produced (Figure 4(b)). The concentration of oxalate produced varied between the isolates, for example at day 28 the amount of oxalate produced by G_01 was 150 $\mu \mathrm{M}$ compared to $30 \mu \mathrm{M}$ (G_05).

\subsection{Elemental Release}

Granite dissolution was measured through the release of key elements ( $\mathrm{Si}, \mathrm{K}, \mathrm{Ca}$ and $\mathrm{Mg}$ ) into the growth medium. The linear elemental release rates $\left(R_{i}^{l}\right)$ from the initial part of the experiment (days 1 to 7 ) were calculated, as shown in Table 3. The $R_{i}^{l}$ values varied between the isolates, for example, the $R_{i}^{l}$ value for $\mathrm{K}$ ranged from $1.11 \pm 0.14 \mathrm{~mol} \cdot \mathrm{m}^{-2} \cdot \mathrm{s}^{-1}$ (G_10) to $3.87 \pm 0.05 \times 10^{-12} \mathrm{~mol} \cdot \mathrm{m}^{-2} \cdot \mathrm{s}^{-1}$ (G_01). Whereas, the $R_{i}^{l}$ value in the abiotic control for K was $1.53 \pm 0.03 \times 10^{-12} \mathrm{~mol} \cdot \mathrm{m}^{-2} \cdot \mathrm{s}^{-1}$. Six of the isolates significantly enhanced the rate of Si, $\mathrm{K}$, Ca and Mg dissolution $(p<0.05)$, as shown in Table 3.

Figure 5 demonstrates a relationship between $\mathrm{Mg}$, Ca, Si and K release and $\mathrm{pH}$. A Pearson's product-moment correlation shows a clear correlation between the $R_{i}^{l}$ values for $\mathrm{Mg}(p=<0.001)$, Ca $(p=<0.001)$, Si $(p=<$ $0.001)$ and $\mathrm{K}(p=<0.001)$ and the maximum decrease in $\mathrm{pH}(-\Delta \mathrm{pH})$. A clear relationship was also demonstrated between the concentration of oxalate in the growth media and $\mathrm{Mg}, \mathrm{Ca}, \mathrm{Si}$ and $\mathrm{K}$ release, as demonstrated in Figure 6.

\section{Discussion}

The aim of this study was to further our understanding of the role that bacteria play in rock weathering, in nutrient 



Figure 3. Cell counts $(\square)$ and change in $\mathrm{pH}(\mathbf{\Delta})$ of the medium over time for each of the isolates: G_22 (A), G_05 (B), G_23 (C), G_20 (D), G_14 (E), G_02 (F), G_23 (G), G_10 (H), G_01 (I). The values reported are the means of three independent experiments, and the standard error associated with these determinations is shown.
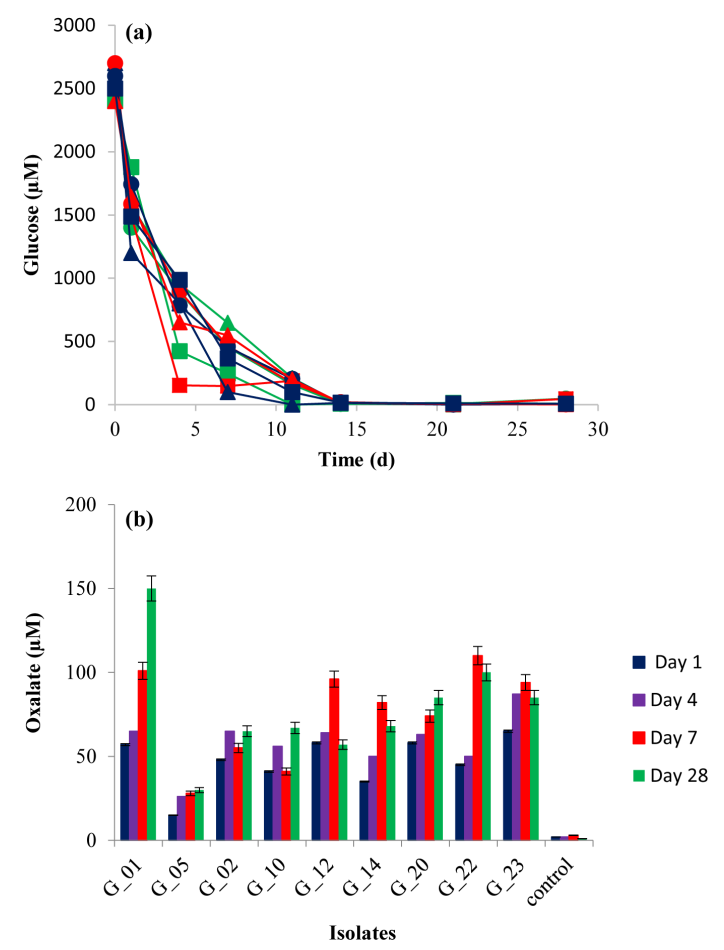

Figure 4. (a) Concentration of glucose in the growth medium for each of the isolates G_22 ( $\square$ ); G_05

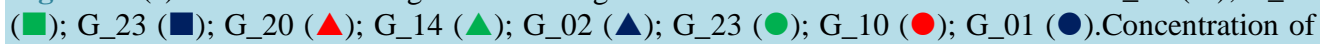
oxalic acid in the growth medium after $1,4,7$ and 28 days. The values reported are the means of three independent experiments, and the standard error associated with these determinations is shown. 
Table 3. Biotic and abiotic mediated linear release rates of Si, K, Ca and Mg dissolution.

\begin{tabular}{|c|c|c|c|c|}
\hline \multirow[b]{2}{*}{ Isolates } & \multicolumn{4}{|c|}{ Dissolution rate $\left(10^{-12} \mathrm{~mol} \cdot \mathrm{m}^{-2} \cdot \mathrm{s}^{-1}\right)$} \\
\hline & Mg & Si & $\mathbf{K}$ & Ca \\
\hline G_01 & $0.98 \pm 0.23^{* *}$ & $0.64 \pm 0.10^{* *}$ & $3.87 \pm 0.05^{* *}$ & $0.99 \pm 0.11^{* *}$ \\
\hline G_05 & $0.51 \pm 0.12^{*}$ & $0.45 \pm 0.01^{*}$ & $2.72 \pm 0.14^{* *}$ & $0.50 \pm 0.04^{* *}$ \\
\hline G_02 & $0.38 \pm 0.13^{*}$ & $0.52 \pm 0.05^{*}$ & $1.82 \pm 0.02^{*}$ & $0.55 \pm 0.08^{*}$ \\
\hline G_10 & $0.62 \pm 0.24^{*}$ & $0.44 \pm 0.05^{*}$ & $1.72 \pm 0.04^{*}$ & $0.57 \pm 0.17^{*}$ \\
\hline G_12 & $0.58 \pm 0.32$ & $0.29 \pm 0.12$ & $1.65 \pm 0.38$ & $0.55 \pm 0.09^{*}$ \\
\hline G_14 & $0.35 \pm 0.21$ & $0.42 \pm 0.11$ & $1.85 \pm 0.01^{*}$ & $0.30 \pm 0.11$ \\
\hline G_20 & $0.79 \pm 0.38^{*}$ & $0.53 \pm 0.11^{*}$ & $3.68 \pm 0.06^{* *}$ & $0.89 \pm 0.11^{* *}$ \\
\hline G_22 & $0.62 \pm 0.2^{*}$ & $0.72 \pm 0.20^{* *}$ & $3.78 \pm 0.12^{* *}$ & $0.89 \pm 0.14^{* *}$ \\
\hline G_23 & $0.65 \pm 0.11^{*}$ & $0.55 \pm 0.16^{*}$ & $1.16 \pm 0.01$ & $0.49 \pm 0.47$ \\
\hline Abiotic control & $0.29 \pm 0.02$ & $0.19 \pm 0.14$ & $1.53 \pm 0.03$ & $0.25 \pm 0.12$ \\
\hline
\end{tabular}

${ }^{* *}$ The value is highly significant $(p<0.01)$; ${ }^{*}$ The value is significant $(p<0.05)$.
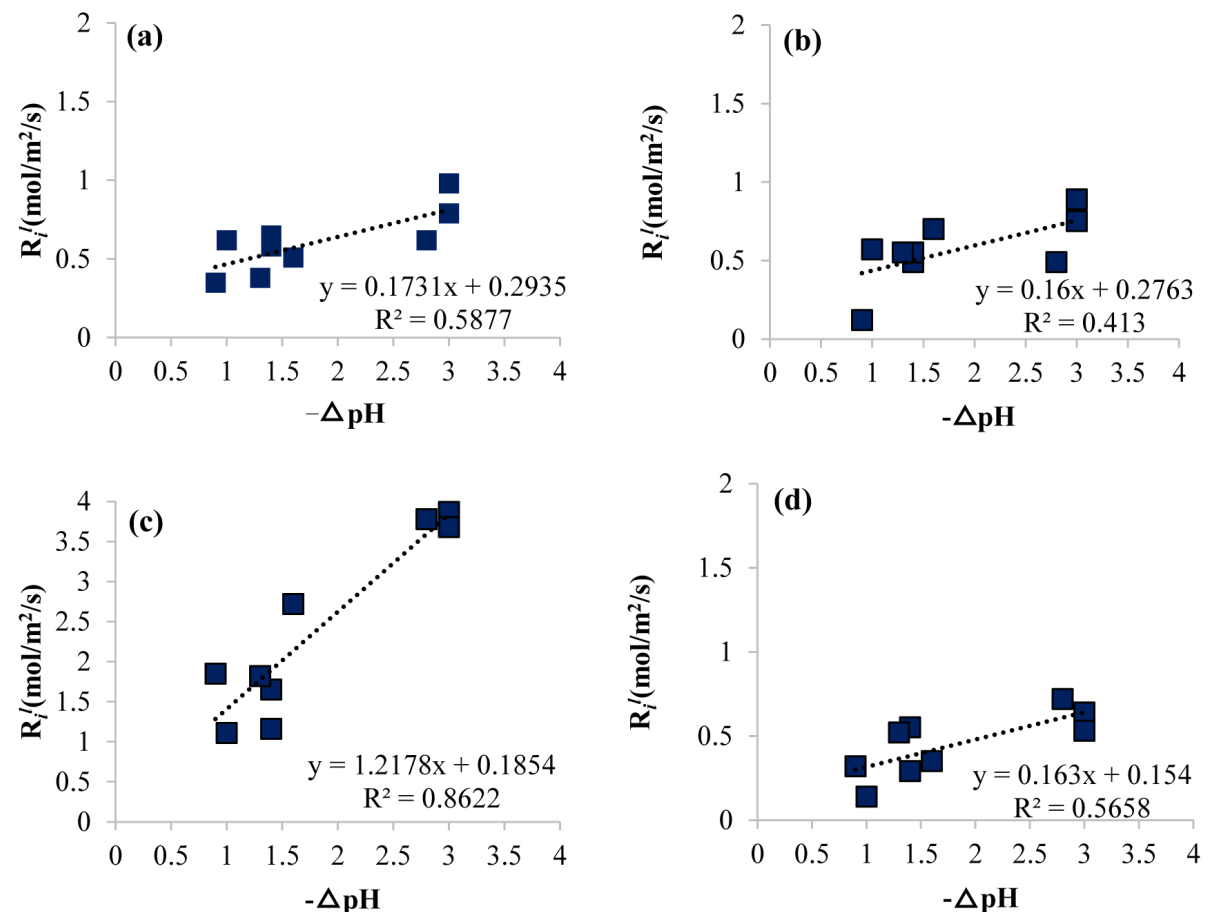

Figure 5. $R_{i}^{l}$ values for $\mathrm{Mg}$ (a), Ca (b), K (c), and Si (d) versus $-\Delta \mathrm{pH}$ (change in $\mathrm{pH}$ ), for each of the bacterium. The $\mathrm{R}$ value was determined using a Pearson's product-moment correlation.

limiting soil. For this study we focused on granite bedrock, because it is the most common rock type in the continental land mass. Samples were collected from below any visible root systems, which reduced the direct influence of the above ground vegetation and the associated rhizosphere bacterial community, which have been shown to influence mineral weathering [3] [39]-[43].

High throughput sequencing was used to obtain a 16S rRNA gene library large enough to be representative of the bacterial community. Although the rarefaction curve did not reach asymptote, we obtained over 276,209 sequences after quality filtering. This allowed for an in-depth analysis of the microbial diversity at the interface between the granite and soil at this location, which demonstrated that the community was dominated by Betaproteobacteria $(40.17 \% \pm 1.33 \%)$. This is in agreement with previous work that has demonstrated that the bacterial 

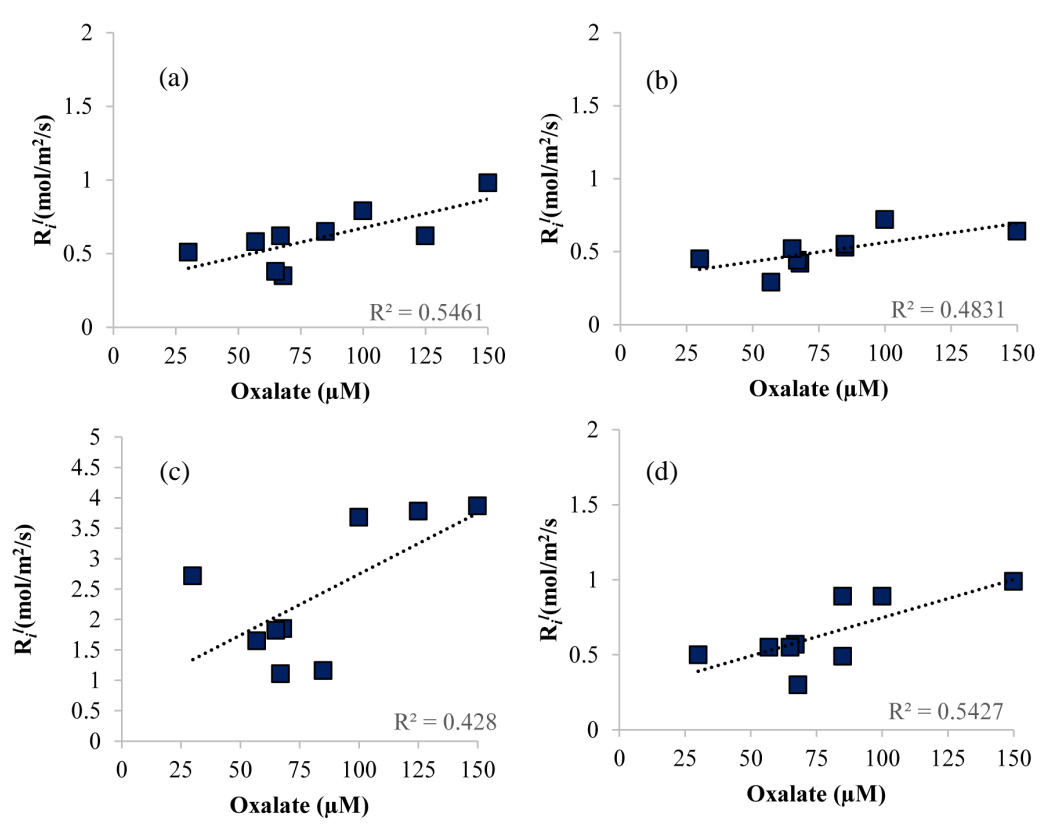

Figure 6. $R_{i}^{l}$ values for $\mathrm{Mg}(\mathrm{a})$, Ca (b), K (c), and Si (d) versus oxalate, for each of the bacterium. The $\mathrm{R}$ value was determined using a Pearson's product-moment correlation.

community on the surface of minerals, such as plagioclase (an important component of granite) and apatite (a phosphate-bearing accessory mineral) are dominated by Beta-proteobacteria [20] [24].

A percentage of these sequences were also identified as unclassified $(19.10 \% \pm 1.04 \%)$. This was potentially due to the short-read lengths, which has made detailed phylogenetic characterisation of the data difficult. Subsequent to this study, 400 bp sequencing has become possible using the Ion Torrent Personal Genome Machine which could, to some extent, overcome this problem. However, in previous studies unclassified sequences have had substantial overlap with the so called "rare biosphere", which are low in abundance and are poorly understood [28] [44], but they may play a crucial role in modifying their environment. For example, in our data set we identified the novel genera Ferribacterium and Ferrithrix in low abundance $(<0.001 \%)$, both of which are involved in iron cycling [45] [46]. These novel genera may play a role in weathering iron-bearing minerals, such as biotite, which is present in granite. However, future work is required to determine the ability of these genera to weather specific silicate minerals.

Linking diversity to mineral weathering requires culturing members of the bacterial community to investigate their weathering potential [1] [47]. The isolation procedure that was used in this study selected for heterotrophic aerobes, which resulted in the isolation of members of the genera Pseudomonas, Bacillus, Paenibacillus, Serratia, Burkholderia and Chromobacterium. Each of the isolates was able to grow using granite as a sole source of bio-essential elements. Six of the isolates Burkholderia (G_20 and G_22), Pseudomonas (G_05 and G_02), Serratia (G_01) and Paenibacillus (G_10) significantly enhanced the release of elements from the granite. Previous laboratory based experiments have demonstrated that members of these genera are able to enhance mineral weathering [3] [14] [42] [48]-[51]. Furthermore, in nutrient limiting forest soil, Uroz et al., [20] [24] demonstrated a potential correlation between the abundance of the genus Burkholderia and the rate of apatite, plagioclase and phlogopite-quartz dissolution.

Under nutrient limiting conditions, bacteria have been shown to produce siderophores, which are known to enhance the rate of iron-oxide and iron-silicate dissolution by approximately one order of magnitude [52]-[55]. The production of siderophores is dependent on the lack of available soluble iron. In this paper, siderophore production was measured in the minimal growth medium, without the granite (no iron source); however, no siderophore production was detected in the presence of granite. This is in agreement with previous studies, which have been unable to detect siderophore production in the presence of basalt or granite [14] [34]. For example, Akers and Magee [56] demonstrated that volcanic ash and silicate rocks repressed the synthesis of the 
siderophore rhodotourulic acid by Rhodotoruliapilimanae. Potentially, sufficient iron was leached from the silicate material in aqueous state $\left(\mathrm{Fe}^{2+}\right)$ to repress siderophore production.

Aerobic heterotrophic bacteria are also known to increase silicate weathering through acidification either through organic acids or proton-promotion [57]-[60]. Several organic acids, such as acetic, gluconic, citric and oxalic have been shown to enhance weathering [52] [59]-[61]. The organic acids act as a ligand, which directly affects mineral dissolution by complexing metal ions at the surface and therefore assisting the release of metals through ligand-promoted dissolution [61]. In this study, a correlation between the concentration of oxalate in the growth medium and dissolution was demonstrated. Although it is difficult to distinguish between organic ligands and proton-mediated dissolution, in acidic conditions, organic acids are more likely to be protonated. Therefore the carboxyl acid is a weaker complex agent of metals, suggesting that proton-mediated dissolution is dominate [62].

\section{Conclusion}

In this study, we used a culture-dependent and culture-independent approach to study the microbial community at the interface between granite bedrock and soil in a nutrient limiting environment. The results from this study suggest that heterotrophic bacteria can enhance the rate of dissolution. Future work will focus on the mechanism bacteria employ to sequester bio-essential elements. This is important for further understanding the regulation of biogeochemical cycling in nutrient limiting environments.

\section{Acknowledgements}

This work was funded by the UK Space Agency as part of an individual fellowship awarded to Olsson-Francis.

\section{References}

[1] Lepleux, C., Uroz, S., Collignon, C., Churin, J.L., Turpault, M.P. and Frey-Klett, P. (2013) A Short-Term Mineral Amendment Impacts the Mineral Weathering Bacterial Communities in an Acidic Forest Soil. Research in Microbiology, 164, 729-739. http://dx.doi.org/10.1016/j.resmic.2013.03.022

[2] Sokolova, T.A. (2011) The Role of Soil Biota in the Weathering of Minerals: A Review of Literature. Eurasian Soil Science, 44, 56-72. http://dx.doi.org/10.1134/S1064229311010121

[3] Uroz, S., Calvaruso, C., Turpault, M.P. and Frey-Klett, P. (2009) Mineral Weathering by Bacteria: Ecology, Actors and Mechanisms. Trends in Microbiology, 17, 378-387. http://dx.doi.org/10.1016/j.tim.2009.05.004

[4] Rogers, J.R., Bennett, P.C. and Choi, W.J. (1998) Feldspars as a Source of Nutrients for Microorganisms. American Mineralogist, 83, 1532-1540. http://dx.doi.org/10.2138/am-1998-11-1241

[5] Kalinowski, B.E., Liermann, L.J., Givens, S. and Brantley, S.L. (2000) Rates of Bacteria-Promoted Solubilization of Fe from Minerals: A Review of Problems and Approaches. Chemical Geology, 169, 357-370. http://dx.doi.org/10.1016/S0009-2541(00)00214-X

[6] Liermann, L.J., Barnes, A.S., Kalinowski, B.E., Zhou, X.Y. and Susan, L. (2000) Microenvironments of pH in Biofilms Grown on Dissolving Silicate Surfaces. Chemical Geology, 171, 1-16. http://dx.doi.org/10.1016/S0009-2541(00)00202-3

[7] Bennett, P.C., Rogers, J.R. and Choi, W.J. (2001) Silicates, Silicate Weathering, and Microbial Ecology. Geomicrobiology Journal, 18, 3-19. http://dx.doi.org/10.1080/01490450151079734

[8] Welch, S.A., Taunton, A.E. and Banfield, J.F. (2002) Effect of Microorganisms and Microbial Metabolites on Apatite Dissolution. Geomicrobiology Journal, 19, 343-367. http://dx.doi.org/10.1080/01490450290098414

[9] Vandevivere, P., Welch, S.A., Ullman, W.J. and Kirchman, D.L. (1994) Enhanced Dissolution of Silicate Minerals by Bacteria at Near-Neutral pH. Microbial Ecology, 27, 241-251. http://dx.doi.org/10.1007/bf00182408

[10] Barker, W.W., Welch, S.A., Chu, S. and Banfield, J.F. (1998) Experimental Observations of the Effects of Bacteria on Aluminosilicate Weathering. American Mineralogist, 83, 1551-1563. http://dx.doi.org/10.2138/am-1998-11-1243

[11] Hiebert, F.K. and Bennett, P.C. (1992) Microbial Control of Silicate Weathering in Organic Rich Ground Water. Science, 258, 278-281. http://dx.doi.org/10.1126/science.258.5080.278

[12] Berthelin, J. and Belgy, G. (1979) Microbial Degradation of Phyllosilicates during Simulation Podzolization. Geoderma, 21, 297-310. http://dx.doi.org/10.1016/0016-7061(79)90004-1

[13] Wu, L., Jacobson, A.D. and Hausner, M. (2008) Characterization of Elemental Release during Microbe-Granite Interactions at $\mathrm{T}=28^{\circ} \mathrm{C}$. Geochimica et Cosmochimica Acta, 72, 1076-1095. http://dx.doi.org/10.1016/j.gca.2007.11.025 
[14] Frey, B., Rieder, S.R., Brunner, I., Plotze, M., Koetzsch, S. and Lapanje, A. (2010) Weathering-Associated Bacteria from the Damma Glacier Forefield: Physiological Capabilities and Impact on Granite Dissolution. Applied and Environmental Microbiology, 76, 4788-4796. http://dx.doi.org/10.1128/AEM.00657-10

[15] Cockell, C.S., Kelly, L.C. and Marteinsson, V. (2013) Actinobacteria: An Ancient Phylum Active in Volcanic Rock Weathering. Geomicrobiology Journal, 30, 706-720. http://dx.doi.org/10.1080/014,90451.2012.758196

[16] Olsson-Francis, K., Simpson, A.E., Wolff-Boenisch, D. and Cockell, C.S. (2012) The Effect of Rock Composition on Cyanobacterial Weathering of Crystalline Basalt and Rhyolite. Geobiology, 10, 434-444. http://dx.doi.org/10.1111/j.1472-4669.2012.00333.x

[17] Wu, L., Jacobson, A.D., Chen, H.C. and Hausner, M. (2007) Characterization of Elemental Release during Microbe-Basalt Interactions at $\mathrm{T}=28^{\circ} \mathrm{C}$. Geochimica et Cosmochimica Acta, 71, 2224-2239. http://dx.doi.org/10.1016/j.gca.2007.02.017

[18] Rogers, J.R. and Bennett, P.C. (2004) Mineral Stimulation of Subsurface Microorganisms: Release of Limiting Nutrients from Silicates. Chemical Geology, 203, 91-108. http://dx.doi.org/10.1016/j.chemgeo.2003.09.001

[19] Carson, J.K., Rooney, D., Gleeson, D.B. and Clipson, N. (2007) Altering the Mineral Composition of Soil Causes a Shift in Microbial Community Structure. FEMS Microbiology Ecology, 61, 414-423. http://dx.doi.org/10.1111/j.1574-6941.2007.00361.x

[20] Uroz, S., Turpault, M.P., Delaruelle, C., Mareschal, L., Pierrat, J.C. and Frey-Klett, P. (2012) Minerals Affect the Specific Diversity of Forest Soil Bacterial Communities. Geomicrobiology Journal, 29, 88-98. http://dx.doi.org/10.1080/01490451.2010.523764

[21] Santelli, C.M., Edgcomb, V.P., Bach, W. and Edwards, K.J. (2009) The Diversity and Abundance of Bacteria Inhabiting Seafloor Lavas Positively Correlate with Rock Alteration. Environmental Microbiology, 11, 86-98. http://dx.doi.org/10.1111/j.1462-2920.2008.01743.x

[22] Gleeson, D.B., Kennedy, N.M., Clipson, N., Melville, K., Gadd, G.M. and McDermott, F.P. (2006) Characterization of Bacterial Community Structure on a Weathered Pegmatitic Granite. Microbial Ecology, 51, 526-534. http://dx.doi.org/10.1007/s00248-006-9052-X

[23] Hutchens, E., Gleeson, D., McDermott, F., Miranda-CasoLuengo, R. and Clipson, N. (2010) Meter-Scale Diversity of Microbial Communities on a Weathered Pegmatite Granite Outcrop in the Wicklow Mountains, Ireland; Evidence for Mineral Induced Selection? Geomicrobiology Journal, 27, 1-14. http://dx.doi.org/10.1080/01490450903232157

[24] Lepleux, C., Turpault, M.P., Oger, P., Frey-Klett, P. and Uroz, S. (2012) Correlation of the Abundance of Betaproteobacteria on Mineral Surfaces with Mineral Weathering in Forest Soils. Applied and Environmental Microbiology, 78, 7114-7119. http://dx.doi.org/10.1128/AEM.00996-12

[25] Olsson-Francis, K., Pearson, V., Boardman, C., Schofield, P. and Summers, S. (2015) A Culture-Independent and Culture-Dependent Study of the Bacteria Community from the Bedrock Soil Interface. Advances in Microbiology, 5, 842857. http://dx.doi.org/10.4236/aim.2015.513089

[26] Griffiths, R.I., Whiteley, A.S., O’Donnell, A.G. and Bailey, M.J. (2000) Rapid Method for Coextraction of DNA and RNA from Natural Environments for Analysis of Ribosomal DNA- and rRNA-Based Microbial Community Composition. Applied and Environmental Microbiology, 66, 5488-5491. http://dx.doi.org/10.1128/AEM.66.12.5488-5491.2000

[27] Whiteley, A.S., Jenkins, S., Waite, I., Kresoje, N., Payne, H., Mullan, B., et al. (2012) Microbial 16S rRNA Ion Tag and Community Metagenome Sequencing Using the Ion Torrent (PGM) Platform. Journal of Microbiological Methods, 91, 80-88. http://dx.doi.org/10.1016/j.mimet.2012.07.008

[28] Sogin, M.L., Morrison, H.G., Huber, J.A., Mark Welch, D., Huse, S.M., Neal, P.R., et al. (2006) Microbial Diversity in the Deep Sea and the Underexplored "Rare Biospheres". Proceedings of the National Academy of Sciences of the United States of America, 103, 12115-12120. http://dx.doi.org/10.1073/pnas.0605127103

[29] Costello, E.K., Lauber, C.L., Hamady, M., Fierer, N., Gordon, J.I. and Knight, R. (2009) Bacterial Community Variation in Human Body Habitats across Space and Time. Science, 326, 1694-1697. http://dx.doi.org/10.1126/science.1177486

[30] Meyer, F., Paarmann, D., D’Souza, M., Olson, R., Glass, E.M., Kubal, M., et al. (2008) The Metagenomics RAST Server-A Public Resource for the Automatic Phylogenetic and Functional Analysis of Metagenomes. BMC Bioinformatics, 9, 386. http://dx.doi.org/10.1186/1471-2105-9-386

[31] Altschul, S.F., Gish, W., Miller, W., Myers, E.W. and Lipman, D.J. (1990) Basic Local Alignment Search Tool. Journal of Molecular Biology, 215, 403-410. http://dx.doi.org/10.1016/s0022-2836(05)80360-2

[32] Schwyn, B. and Neilands, J.B. (1987) Universal Chemical Assay for the Detection and Determination of Siderophores. Analytical Biochemistry, 160, 47-56. http://dx.doi.org/10.1016/0003-2697(87)90612-9

[33] Payne, S.M. (1994) Detection, Isolation, and Characterization of Siderophores. Methods in Enzymology, 235, 329-344. http://dx.doi.org/10.1016/0076-6879(94)35151-1 
[34] Olsson-Francis, K., Van Houdt, R., Mergeay, M., Leys, N. and Cockell, C.S. (2010) Microarray Analysis of a Microbe-Mineral Interaction. Geobiology, 8, 446-456. http://dx.doi.org/10.1111/j.1472-4669.2010.00253.x

[35] Summers, S., Whiteley, A.S., Kelly, L. and Cockell, C.S. (2013) Land Coverage Influences the Bacterial Community Composition in the Critical Zone of a Sub-Artic Basaltic Environment. FEMS Microbiology Ecology, 86, 381-393. http://dx.doi.org/10.1111/1574-6941.12167

[36] Pirt, S.J. (1978) Principles of Microbe and Cell Cultivation. Blackwell, Oxford.

[37] Legendre, P., Oksanen, J. and ter Braak, C.J.F. (2011) Testing the Significance of Canonical Axes in Redundancy Analysis. Methods in Ecology and Evolution, 2, 269-277. http://dx.doi.org/10.1111/j.2041-210X.2010.00078.X

[38] Clarke, K. (1993) Non-Parametric Multivariate Analyses of Changes in Community Structure. Australian Journal of Ecology, 18, 117-143. http://dx.doi.org/10.1111/j.1442-9993.1993.tb00438.x

[39] Goldstein, A.H., Braverman, K. and Osorio, N. (1999) Evidence for Mutualism between a Plant Growing in a Phosphate-Limited Desert Environment and a Mineral Phosphate Solubilizing (MPS) Rhizobacterium. FEMS Microbiology Ecology, 30, 295-300. http://dx.doi.org/10.1111/j.1574-6941.1999.tb00657.x

[40] Acevedo, E., Galindo-Castaneda, T., Prada, F., Navia, M. and Romero, H.M. (2014) Phosphate-Solubilizing Microorganisms Associated with the Rhizosphere of oil Palm (Elaeis guineensis Jacq.) in Colombia. Applied Soil Ecology, 80, 26-33. http://dx.doi.org/10.1016/j.apsoil.2014.03.011

[41] Vazquez, P., Holguin, G., Puente, M.E., Lopez-Cortes, A. and Bashan, Y. (2000) Phosphate-Solubilizing Microorganisms Associated with the Rhizosphere of Mangroves in a Semiarid Coastal Lagoon. Biology and Fertility of Soils, 30, 460-468. http://dx.doi.org/10.1007/s003740050024

[42] Uroz, S., Calvaruso, C., Turpault, M.P., Pierrat, J.C., Mustin, C. and Frey-Klett, P. (2007) Effect of the Mycorrhizosphere on the Genotypic and Metabolic Diversity of the Bacterial Communities Involved in Mineral Weathering in a Forest Soil. Applied and Environmental Microbiology, 73, 3019-3027. http://dx.doi.org/10.1128/aem.00121-07

[43] Calvaruso, C., Turpault, M.P., Leclerc, E. and Frey-Klett, P. (2007) Impact of Ectomycorrhizosphere on the Functional Diversity of Soil Bacterial and Fungal Communities from a Forest Stand in Relation to Nutrient Mobilization Processes. Microbial Ecology, 54, 567-577. http://dx.doi.org/10.1007/s00248-007-9260-z

[44] Neufeld, J.D., Li, J. and Mohn, W.W. (2008) Scratching the Surface of the Rare Biosphere with Ribosomal Sequence Tag Primers. FEMS Microbiology Letters, 283, 146-153. http://dx.doi.org/10.1111/j.1574-6968.2008.01124.x

[45] Cummings, D.E., Caccavo, F., Spring, S. and Rosenzweig, R.F. (1999) Ferribacterium limneticum, gen. nov., sp. nov., an Fe(III)-Reducing Microorganism Isolated from Mining-Impacted Freshwater Lake Sediments. Archives of Microbiology, 171, 183-188. http://dx.doi.org/10.1007/s002030050697

[46] Johnson, D.B., Bacelar-Nicolau, P., Okibe, N., Thomas, A. and Hallberg, K.B. (2009) Ferrimicrobium acidiphilum gen. nov., sp nov and Ferrithrix thermotolerans gen. nov., sp nov.: Heterotrophic, Iron-Oxidizing, Extremely Acidophilic Actinobacteria. International Journal of Systematic and Evolutionary Microbiology, 59, 1082-1089. http://dx.doi.org/10.1099/ijs.0.65409-0

[47] Huang, J., Sheng, X.F., Xi, J., He, L.Y., Huang, Z., Wang, Q., et al. (2014) Depth-Related Changes in Community Structure of Culturable Mineral Weathering Bacteria and in Weathering Patterns Caused by Them along Two Contrasting Soil Profiles. Applied and Environmental Microbiology, 80, 1542-1550. http://dx.doi.org/10.1128/AEM.04211-13

[48] Hameeda, B., Reddy, Y.H., Rupela, O.P., Kumar, G.N. and Reddy, G. (2006) Effect of Carbon Substrates on Rock Phosphate Solubilization by Bacteria from Composts and Macrofauna. Current Microbiology, 53, 298-302. http://dx.doi.org/10.1007/s00284-006-0004-y

[49] Kim, Y.H., Bae, B. and Choung, Y.K. (2005) Optimization of Biological Phosphorus Removal from Contaminated Sediments with Phosphate-Solubilizing Microorganisms. Journal of Bioscience and Bioengineering, 99, 23-29. http://dx.doi.org/10.1263/jbb.99.23

[50] Kalinowski, B.E., Liermann, L.J., Brantley, S.L., Barnes, A. and Pantano, C.G. (2000) X-Ray Photoelectron Evidence for Bacteria-Enhanced Dissolution of Hornblende. Geochimica et Cosmochimica Acta, 64, 1331-1343. http://dx.doi.org/10.1016/S0016-7037(99)00371-3

[51] Abdulla, H. (2009) Bioweathering and Biotransformation of Granitic Rock Minerals by Actinomycetes. Microbial Ecology, 58, 753-761. http://dx.doi.org/10.1007/s00248-009-9549-1

[52] Welch, S.A. and Ullman, W.J. (1996) Feldspar Dissolution in Acidic and Organic Solutions: Compositional and pH Dependence of Dissolution Rate. Geochimica et Cosmochimica Acta, 60, 2939-2948. http://dx.doi.org/10.1016/0016-7037(96)00134-2

[53] Buss, H.L., Luttge, A. and Brantley, S.L. (2007) Etch Pits and Leached Layers on Iron-Silicate Surfaces during Siderophore-Promoted Dissolution. Chemical Geology, 240, 326-342. http://dx.doi.org/10.1016/j.chemgeo.2007.03.003 
[54] Hersman, L., Lloyd, T. and Sposito, G. (1995) Siderophore-Promoted Dissolution of Hematite. Geochimica et Cosmochimica Acta, 59, 3327-3330. http://dx.doi.org/10.1016/0016-7037(95)00221-K

[55] Kraemer, S.M. (2004) Iron Oxide Dissolution and Solubility in the Presence of Siderophores. Aquatic Sciences, 66, 3-18. http://dx.doi.org/10.1007/s00027-003-0690-5

[56] Akers, H.A. and Magee, K.P. (1985) The Repression of Siderophore Synthesis by Mount Saint Helens Ash and Silicate Rock Standards. Experientia, 41, 1354-1355. http://dx.doi.org/10.1007/BF01952093

[57] Furrer, G. and Stumm, W. (1986) The Coordination Chemistry of Weathering: I. Dissolution Kinetics of $\delta$ - $\mathrm{Al}_{2} \mathrm{O}_{3}$ and BeO. Geochimica et Cosmochimica Acta, 50, 1847-1860. http://dx.doi.org/10.1016/0016-7037(86)90243-7

[58] Liermann, L.J., Kalinowski, B.E., Brantley, S.L. and Ferry, J.G. (2000) Role of Bacterial Siderophores in Dissolution of Hornblende. Geochimica et Cosmochimica Acta, 64, 587-602. http://dx.doi.org/10.1016/S0016-7037(99)00288-4

[59] Drever, J.I. and Stillings, L.L. (1997) The Role of Organic Acids in Mineral Weathering. Colloids and Surfaces A: Physicochemical and Engineering Aspects, 120, 167-181. http://dx.doi.org/10.1016/S0927-7757(96)03720-X

[60] Welch, S.A., Taunton, A.E. and Banfield, J.F. (2002) Effect of Microorganisms and Microbial Metabolites on Apatite Dissolution. Geomicrobiology Journal, 19, 343-367. http://dx.doi.org/10.1080/01490450290098414

[61] Welch, S.A. and Ullman, W.J. (1993) The Effect of Organic Acids on Plagioclase Dissolution Rates and Stoichiometry. Geochimica et Cosmochimica Acta, 57, 2725-2736. http://dx.doi.org/10.1016/0016-7037(93)90386-B

[62] Buffle, J. (1988) Complexation Reactions in Aquatic Systems. Wiley, New York, 692. 